\title{
Physical Training Inhibits the Fibrosis Formation in Alzheimer's Disease Kidney Influencing the TGF $\beta$ Signaling Pathways
}

\author{
Vince Szegeczki ${ }^{\mathrm{a}, 1}$, Helga Perényi ${ }^{\mathrm{a}, 1}$, Gabriella Horváth ${ }^{\mathrm{b}}$, Barbara Hinnah ${ }^{\mathrm{a}}$, Andrea Tamás ${ }^{\mathrm{b}}$, \\ Zsolt Radák $^{\mathrm{c}}$, Dóra Ábrahám ${ }^{\mathrm{c}}$, Róza Zákány ${ }^{\mathrm{a}}$, Dóra Reglodi ${ }^{\mathrm{b}, 1}$ and Tamás Juhász ${ }^{\mathrm{a}, 1, *}$ \\ ${ }^{a}$ Department of Anatomy, Histology and Embryology, Faculty of Medicine, University of Debrecen, Debrecen, \\ Hungary \\ ${ }^{\mathrm{b}}$ Department of Anatomy, PTE-MTA PACAP Research Team, University of Pécs Medical School, Pécs, Hungary \\ ${ }^{\mathrm{c}}$ Research Institute of Sport Science, University of Physical Education, Budapest, Hungary
}

Accepted 16 March 2021

Pre-press 19 April 2021

\begin{abstract}
.
Background: Alzheimer's disease (AD) is a neurodegenerative illness, with several peripheral pathological signs such as accumulation of amyloid- $\beta$ (A $\beta$ ) plaques in the kidney. Alterations of transforming growth factor $\beta$ (TGF $\beta$ ) signaling in the kidney can induce fibrosis, thus disturbing the elimination of $A \beta$.

Objective: A protective role of increased physical activity has been proven in $\mathrm{AD}$ and in kidney fibrosis, but it is not clear whether TGF $\beta$ signalization is involved in this effect.

Methods: The effects of long-term training on fibrosis were investigated in the kidneys of mice representing a model of $\mathrm{AD}$ (B6C3-Tg(APPswe,PSEN1dE9)85Dbo/J) by comparing wild type and AD organs. Alterations of canonical and non-canonical TGF $\beta$ signaling pathways were followed with PCR, western blot, and immunohistochemistry.

Results: Accumulation of collagen type I and interstitial fibrosis were reduced in kidneys of AD mice after long-term training. $\mathrm{AD}$ induced the activation of canonical and non-canonical TGF $\beta$ pathways in non-trained mice, while expression levels of signal molecules of both TGF $\beta$ pathways became normalized in trained AD mice. Decreased amounts of phosphoproteins with molecular weight corresponding to that of tau and the cleaved C-terminal of A $\beta P P$ were detected upon exercising, along with a significant increase of PP2A catalytic subunit expression.

Conclusion: Our data suggest that physical training has beneficial effects on fibrosis formation in kidneys of AD mice and TGF $\beta$ signaling plays a role in this phenomenon.
\end{abstract}

Keywords: Alzheimer's disease, fibrosis, physical activity, Smad, TGF $\beta$

\section{INTRODUCTION}

Alzheimer's disease (AD) is the most common form of dementia, but its systemic appearance has

\footnotetext{
${ }^{1}$ These authors contributed equally to this work.

*Correspondence to: Tamás Juhász, Department of Anatomy, Histology and Embryology, University of Debrecen, Faculty of Medicine, Nagyerdei krt. 98, H-4032, Debrecen, Hungary. Tel.: +36 52255 567; Fax: +36 52255 115; E-mail: juhaszt@anat.med. unideb.hu.
}

begun to be discussed only in the last decades. Although great efforts have been made to develop drugs and disease-modifying therapies, there are no curative procedures available to date [1-3]. Formation of amyloid plaques and abnormal function of amyloid- $\beta$ protein precursor (A $\beta P P)$ are considered as first signs of the illness not only in the central nervous system (CNS) but also in the periphery [4]. Compelling evidence supports the pivotal role of amyloid- $\beta(\mathrm{A} \beta)$ in the pathogenesis of $\mathrm{AD}[5]$ 
pointing out that the decreased clearance of $A \beta$ is one of the key processes in the pathomechanism. In $\mathrm{AD}$, several peripheral organs are involved such as testis [5], pancreas [6], and kidney [7], highlighting the development of a complex systemic disease with multiple targets [8]. It has been proven that the kidney is involved in $A \beta$ clearance [9]. Moreover, serum concentration of $A \beta$ is significantly elevated in chronic kidney disease (CKD) patients $[10,11]$. A $\beta$ accumulation has also been demonstrated in the kidney [12], leading to a filtration disorder. Proper filtration is partly regulated by transforming growth factor $\beta$ (TGF $\beta$ ), which is a master cytokine in the pathogenesis of renal inflammation and fibrosis [13], and it is also known as an important factor in AD pathogenesis [14]. In AD, TGF $\beta$ signaling plays a role in microglia activation and astrocyte-mediated neuroprotection [15]. Additionally, altered expression of TGF $\beta$ also affects the inflammation in the CNS and peripheral tissues $[13,16]$.

TGF $\beta$ has three isoforms: TGF $\beta 1$, TGF $\beta 2$, and TGF $\beta 3$ [17]. TGF $\beta 1$ takes part in several processes such as fetal development, control of cell growth and differentiation, fibrosis and scar tissue formation, tumor growth, and immune response [18]. It is an important cytokine in fibrosis formation in various organs such as liver and kidney [19]. TGF $\beta 1$ forms dimers, which first bind to TGF $\beta$ type II receptor (TGFBRII), then activate TGF $\beta$ receptor type I (TGF $\beta R I)$ Ser/Thr kinase, initiating intracellular signaling complex-formation of Smad transcription factors. In the canonical TGF $\beta$ signaling pathway, Smad2/3 transcription factors are phosphorylated and, after complex formation with Smad4, translocate into the nucleus [20]. Several genes can be affected by TGF $\beta 1$ activation as it induces the expression of different collagens, controls cell proliferation, affects apoptosis [20] and regulates matrix metalloproteinase (MMP) expression [21]. The non-canonical TGF $\beta$ signaling pathway initiates the activation of MAPKes by phosphorylation which in turn can induce further TGF $\beta$ expression [22]. JNK and p38 kinases as TGF $\beta$ targets are identified in renal fibrosis and regulate apoptosis [23].

Physical activity has been shown to exert beneficial effects in human patients. Exercising can regulate and postpone the manifestation of $\mathrm{AD}[24,25]$ and reduction of $\mathrm{AD}$ biomarkers such as tau and $\mathrm{A} \beta$ in plasma have also been reported [25]. Physical activity has been found to reduce the incidence of $\mathrm{AD}, \mathrm{AD}$-associated neuropathological burden, and cognitive decline [26]. Although numerous studies have been published about the benefits of physical activity on AD formation [27], the intracellular mechanisms involved in these positive effects have not been discussed in detail. There are a few animal models where genetically modified mice with tau and $\mathrm{A} \beta$ overexpression have been tested during physical exercise. In these models it has been proven that elevated physical activity was able to postpone the manifestation of AD [28, 29]. Furthermore, it was demonstrated that long-term training of these mice had positive effects on peripheral organ dysfunctions in AD. Physical activity altered the PACAP-BMP crosstalk in AD kidneys via normalizing the expression of collagen type IV and $A \beta$ accumulation [30]. Moreover, detailed analysis of protective function of training on Sox9 expression in AD testis has been published [31]. Active training also affects TGF $\beta$ signaling as it suppresses renal inflammation and subsequent fibrosis [32]. In addition, TGF $\beta$ and its signaling are important for adult bone remodeling which is disturbed in kidney fibrosis [33]. Subsequently, our major hypothesis was that long-term physical training has a systemic effect on TGF $\beta$ signaling which can regulate kidney matrix production in $\mathrm{AD}$. The alterations of these signaling pathways may result in decreased kidney fibrosis and normalize $A \beta$ clearance. Therefore, our aim was to elucidate the relationship between TGF $\beta$-signaling and beneficial effects of physical training on kidney fibrosis in $\mathrm{AD}$.

In our experiments we present evidence that longterm training has direct effects on TGF $\beta$ signalization in kidneys of $\mathrm{AD}$ mice. Furthermore, we show that increased physical exercise decreases kidney fibrosis via normalizing canonical and non-canonical TGF $\beta$ signalization.

\section{MATERIAL AND METHODS}

\section{Animals}

Male Alzheimer-transgenic $(n=5) \quad(\mathrm{B} 6 \mathrm{C} 3-\mathrm{Tg}$ (APPswe,PSEN1dE9)85Dbo/J) mice were used to follow the effect of AD. Three-month-old wild type (WT) (no transgenic modulation and no training) $(n=5)$, Alzheimer's transgenic mice (AD) $(n=5)$, and trained $\mathrm{AD}$ (TAD) $(n=5)$ mice were kept under light/dark cycles of $12 / 12 \mathrm{~h}$ with food and water ad libitum. Interval treadmill running was applied for the exercise and combined group. Previously all exercising animals were habituated with the motordriven treadmill (Columbus Inst., Columbus Ohio, 
USA) and the running speed for 2 weeks. Training was performed four times a week, for $60 \mathrm{~min}$. Each training session lasted 10 cycles, each cycle consisted of $4 \mathrm{~min}$ of high intensity and $2 \mathrm{~min}$ of low intensity running. Low intensity running speed was permanent during the experiment meaning a speed of $10 \mathrm{~m} / \mathrm{min}$. While high intensity running speed started at $16 \mathrm{~m} / \mathrm{min}$ and was elevated every third week with $1 \mathrm{~m} / \mathrm{min}$ until $20 \mathrm{~m} / \mathrm{min}$ was reached. Control and Nutrition group were also habituated with the treadmill and stayed there for $5 \mathrm{~min} /$ day on a standing treadmill [28]. Experiments were started with 3-month-old animals and terminated at 10 months of age. The study was carried out in accordance with ethical guidelines (ethical permission number for this study: PEI/001/2105-6/2014, Semmelweis University, Hungary). Phire Animal Tissue Direct PCR Kit was used for genotyping the animals (Thermo Fischer Scientific, Waltham, MA, USA) according to the manufacturer's instructions.

\section{Light microscopical morphology}

After all the cognitive tests were finished, 10month-old mice were anaesthetized with an intraperitoneal injection of ketamine (Richter, concentration: $100 \mathrm{mg} / \mathrm{ml}$ )/xylazine (Produlab Pharma, concentration: $20 \mathrm{mg} / \mathrm{ml}$ ) cocktail in a dose of $0.1 \mathrm{ml} / 10 \mathrm{~g}$ bodyweight and transcardially perfused with heparinized ice-cold saline [28] and kidneys were removed. Tissue samples were washed in PBS three times and fixed in a 4:1 mixture of absolute ethanol and $40 \%$ formaldehyde, then embedded in paraffin. For Masson's trichrome staining (Sigma-Aldrich, MO, USA) serial sections were made and fibrotic tissue was visualized. Staining protocol was carried out according to the manufacturer's instructions. DP74 camera (Olympus Corporation, Tokyo, Japan) on Olympus Bx53 microscope (Olympus Corporation, Tokyo, Japan) was used to take photomicrographs.

\section{Immunohistochemistry}

Immunohistochemistry was performed on kidney tissue samples from WT, AD mice, and TAD mice to visualize localization of Smad2, PCNA (proliferating cell nuclear antigen), and collagen type I (Col. I) [30]. Kidneys were fixed in a 4:1 mixture of absolute ethanol and $40 \%$ formaldehyde and washed in $70 \%$ ethanol. After embedding serial sections were made, deparaffination was followed by rinsing in PBS ( $\mathrm{pH}$ 7.4). Non-specific binding sites were blocked with $1 \%$ bovine serum albumin dissolved in PBS (Amresco LLC, Solon, OH, USA). Sections were incubated with polyclonal Smad2 (Sigma-Aldrich, MO, USA) at a dilution of 1:500, PCNA (Cell Signaling, Danvers, MA, USA) at a dilution of 1:800 or Col. I (Sigma-Aldrich, MO, USA) antibody at a dilution of $1: 500$ at $4{ }^{\circ} \mathrm{C}$ overnight. Primary antibodies were visualized with the addition of anti-rabbit Alexa Fluor 555 secondary antibody (Life Technologies Corporation, Carlsbad, CA, USA) was used at a dilution of 1:1000. Samples were mounted in Vectashield mounting medium (Vector Laboratories, Peterborough, England) containing DAPI (4',6-Diamidino-2-phenylindole dihydrochloride) for nuclear DNA staining. Anti-rabbit Alexa Fluor 555 was used without the primary antibodies for negative control. Photomicrographs were taken using DP74 camera (Olympus Corporation, Tokyo, Japan) on Olympus Bx53 microscope (Olympus Corporation, Tokyo, Japan) for the visualization of Col. I. Images were acquired using cellSense Entry 1.5 software (Olympus, Shinjuku, Tokyo, Japan) with constant camera settings to allow comparison of fluorescent signal intensities. For Smad2 and PCNA detection an Olympus FV3000 confocal microscope (Olympus Co. Tokyo, Japan) was used applying $60 \times$ oil immersion objective (NA: 1.42). For excitation, laser lines of $543 \mathrm{~nm}$ were used. The average pixel time was $4 \mu \mathrm{s}$. Z image series of $1 \mu \mathrm{m}$ optical thickness were recorded in sequential scan mode. Images of Alexa555 and DAPI were overlaid using Adobe Photoshop version 10.0 software. Contrast of images was equally increased without changing constant settings.

\section{RT-PCR analysis}

Kidneys of WT $(n=5), \operatorname{AD}(n=5)$, and TAD $(n=5)$ were mechanically ground and were dissolved in Trizol (Applied Biosystems, Foster City, CA, USA), after $30 \mathrm{~min}$ incubation on $4^{\circ} \mathrm{C}$ and total RNA was isolated [30]. RNA was harvested in RNase-free water and stored at $-70^{\circ} \mathrm{C}$. High Capacity RT kit was used for reverse transcription (Applied Biosystems, Foster City, CA, USA). For the sequences of the applied primer pairs and details of polymerase chain reactions, see Table 1. Amplifications were performed in a thermal cycler (Labnet MultiGene ${ }^{\mathrm{TM}}$ 96-well Gradient Thermal Cycler; Labnet International, Edison, NJ, USA) as follows: $95^{\circ} \mathrm{C}, 2 \mathrm{~min}$, followed by 35 cycles (denaturation, $94^{\circ} \mathrm{C}, 30 \mathrm{~s}$, annealing for $45 \mathrm{~s}$ at optimized temperatures as given in Table 1; extension, $72^{\circ} \mathrm{C}, 90 \mathrm{~s}$ ) and then $72^{\circ} \mathrm{C}$, 
Table 1

Nucleotide sequences, amplification sites, GenBank accession numbers, amplimer sizes and PCR reaction conditions for each primer pair are shown

\begin{tabular}{|c|c|c|c|c|c|}
\hline Gene & Primer & Nucleotide sequence $\left(5^{\prime} \rightarrow 3^{\prime}\right)$ & GenBank ID & $\begin{array}{c}\text { Annealing } \\
\text { temperature }\end{array}$ & $\begin{array}{c}\text { Amplimer } \\
\text { size }(b p)\end{array}$ \\
\hline \multirow[t]{2}{*}{ TGF $\beta 1$} & sense & AGCTGCGCTTGCAGAGATTA (1328-1347) & NM_011577.2 & $60^{\circ} \mathrm{C}$ & 189 \\
\hline & antisense & AGCCCTGTATTCCGTCTCCT (1516-1497) & & & \\
\hline \multirow[t]{2}{*}{ TGFßRI } & sense & CCACAAACAGTGGCGGC (68-84) & NM_001312868.1 & $59^{\circ} \mathrm{C}$ & 121 \\
\hline & antisense & AAACACTGTAATGCCTTCGC (188-169) & & & \\
\hline \multirow[t]{2}{*}{ TGF $\beta$ RII } & sense & CCAAGTCGGATGTGGAAATGG (412-432) & NM_009371.3 & $59^{\circ} \mathrm{C}$ & 177 \\
\hline & antisense & TGTCGCAAGTGGACAGTCTC (588-569) & & & \\
\hline \multirow[t]{2}{*}{ Smad2 } & sense & AGGATGATGGGGACGGGAAT (211-230) & NM_001252481.1 & $53^{\circ} \mathrm{C}$ & 197 \\
\hline & antisense & AGCCCGGTAAATCTACCCAGAA (407-386) & & & \\
\hline \multirow[t]{2}{*}{ Smad3 } & sense & GTTGGAAGAAGGGCGAGCAG (367-386) & NM_016769.4 & $61^{\circ} \mathrm{C}$ & 167 \\
\hline & antisense & ATCCAGTGACCTGGGGATGGTA (533-512) & & & \\
\hline \multirow[t]{2}{*}{ ERK } & sense & GCTGAAGCGCCATTCAAGTT (1212-1231) & NM_001038663.1 & $59^{\circ} \mathrm{C}$ & 179 \\
\hline & antisense & ACTTACACCATCTCTCССТTGC (1390-1369) & & & \\
\hline \multirow[t]{2}{*}{ p38 } & sense & TACCTTGCCACTTTGGCTTCT (1828-1848) & NM_001168508.1 & $59^{\circ} \mathrm{C}$ & 342 \\
\hline & antisense & TGCACCATGGCCTTCCTAAA (2169-2150) & & & \\
\hline \multirow[t]{2}{*}{ JNK } & sense & AACTGTTCCCCGATGTGCTT (865-884) & NM_001310452.1 & $60^{\circ} \mathrm{C}$ & 194 \\
\hline & antisense & GATCTTTGGTGGTGGGGCTT (1058-1039) & & & \\
\hline \multirow[t]{2}{*}{ PP2AC } & sense & AAGGCCTCCCCTCTTGTTGT (1571-1590) & NM_017374.3 & $61^{\circ} \mathrm{C}$ & 259 \\
\hline & antisense & CCAGTCGTGCCCACTGATAC (1829-1810) & & & \\
\hline \multirow[t]{2}{*}{ PP2BC } & sense & TTTGCTTGAATGCCCTTCTTTC (3494-3515) & NM_001293622.1 & $58^{\circ} \mathrm{C}$ & 216 \\
\hline & antisense & CTGCACTATGGTGTCGTGTT (3709-3690) & & & \\
\hline \multirow[t]{2}{*}{$\mathrm{p} 21$} & sense & CAGAATAAAAGGTGCCACAGGC (110-131) & NM_001111099.2 & $61^{\circ} \mathrm{C}$ & 193 \\
\hline & antisense & CGTCTCCGTGACGAAGTCAA (302-283) & & & \\
\hline \multirow[t]{2}{*}{ PCNA } & sense & TATGTCTGCAGATGTGCCCC (828-847) & NM_011045.2 & $59^{\circ} \mathrm{C}$ & 175 \\
\hline & antisense & AAAGACCTCAGGACACGCTG (1002-983) & & & \\
\hline \multirow[t]{2}{*}{ Caspase3 } & sense & ACATGGGAGCAAGTCAGTGG (289-308) & NM_001284409.1 & $59^{\circ} \mathrm{C}$ & 149 \\
\hline & antisense & CGTCCACATCCGTACCAGAG $(437-418)$ & & & \\
\hline \multirow[t]{2}{*}{ MMP9 } & sense & CGCTCATGTACCCGCTGTAT (1288-1307) & NM_013599.4 & $60^{\circ} \mathrm{C}$ & 180 \\
\hline & antisense & CAAGAAGGAAGGCTGGAAAA (1467-1448) & & & \\
\hline \multirow[t]{2}{*}{ Colla1 } & sense & GCTGGGACATGGGGTTCTTG (5042-5061) & NM_007393.5 & $60^{\circ} \mathrm{C}$ & 191 \\
\hline & antisense & GCATGTCCGATGTTTCCAGTC (5232-5212) & & & \\
\hline \multirow[t]{2}{*}{ Actin } & sense & GCCAACCGTGAAAAGATGA (419-437) & NM_007393.5 & $54^{\circ} \mathrm{C}$ & 462 \\
\hline & antisense & CAAGAAGGAAGGCTGGAAAA (861-880) & & & \\
\hline
\end{tabular}

7 min. Actin was used as internal control. PCR products were analyzed using a $1.2 \%$ agarose gel containing ethidium bromide and documented with FluorchemE geldocumetary system (ProteinSimple, CA, USA). Optical densities of PCR product signals were determined by using ImageJ $1.40 \mathrm{~g}$ freeware. Before optical density measurements, we made individual calibrations on every photomicrograph. Then we increased the magnification of the photos to reach individual pixel size and with freehanded method lanes were precisely circled and measured the integrated density of the area. The pixels were measured in 5 independent experiments by 3 independent operators. Signals first were compared with the WT actin for better comparison of expression differences in $\mathrm{AD}$ and TAD mice. Numbers below the lanes show the statistical analysis of the experiments where every separate experiment (at least 5) was normalized for its own actin signal and then statistical differences were calculated.

\section{Western blot analysis}

Kidneys of WT $(n=5), \mathrm{AD}(n=5)$, and TAD mice $(n=5)$ were washed in physiological saline and stored at $-70^{\circ} \mathrm{C}$. Samples were mechanically ground in liquid nitrogen and were collected in $100 \mu \mathrm{L}$ of homogenization RIPA (Radio Immuno Precipitation Assay)-buffer ( $150 \mathrm{mM}$ sodium chloride; $1.0 \%$ NP40, $0.5 \%$ sodium deoxycholate; $50 \mathrm{mM}$ Tris, pH 8.0) containing protease inhibitors (Aprotinin $(10 \mu \mathrm{g} / \mathrm{mL}), 5 \mathrm{mM}$ Benzamidine, Leupeptin $(10 \mu \mathrm{g} / \mathrm{mL})$, Trypsine inhibitor $(10 \mu \mathrm{g} / \mathrm{mL}), 1 \mathrm{mM}$ PMSF, $5 \mathrm{mM}$ EDTA, $1 \mathrm{mM}$ EGTA, $8 \mathrm{mM} \mathrm{Na}$ Fluoride, $1 \mathrm{mM}$ Na-orthovanadate). Pellets were sonicated by pulsing burst for $30 \mathrm{~s}$ at 40 A (ColeParmer, IL, USA). Total cell lysates for western blot analyses were prepared [30]. $20 \mu \mathrm{g}$ protein was separated in $7.5 \%$ SDS-polyacrylamide gels for the detection of TGF $\beta 1$, TGF $\beta R 1$, TGF $\beta R 2$, Smad2, Smad3, ERK1/2, P-ERK1/2, p38, P-p38, 
Table 2

Antibodies used in the experiments

\begin{tabular}{lccc}
\hline Antibody & Host animal & Dilution & Distributor \\
\hline Anti-TGFß1 & rabbit, polyclonal, & $1: 800$ & Cell Signaling, Danvers, MA, USA \\
Anti-TGFßRI & mouse, monoclonal, & $1: 500$ & Cell Signaling, Danvers, MA, USA \\
Anti-TGFßRI & rabbit, polyclonal, & $1: 500$ & Cell Signaling, Danvers, MA, USA \\
Anti-Smad2 & rabbit, polyclonal, & $1: 500$ & Cell Signaling, Danvers, MA, USA \\
Anti-Smad3 & rabbit, polyclonal, & $1: 500$ & Cell Signaling, Danvers, MA, USA \\
Anti-ERK1/2 & rabbit, polyclonal, & $1: 2000$ & Sigma-Aldrich, St. Louis, MO, USA \\
Anti-P-ERK1/2 & mouse, monoclonal, & $1: 800$ & Sigma-Aldrich, St. Louis, MO, USA \\
Anti-p38 & rabbit, polyclonal, & $1: 800$ & Cell Signaling, Danvers, MA, USA \\
Anti-P-p38 & rabbit, polyclonal, & $1: 500$ & Cell Signaling, Danvers, MA, USA \\
Anti-JNK & rabbit, polyclonal & $1: 800$ & Cell Signaling, Danvers, MA, USA \\
Anti-PP2AC & mouse, monoclonal, & $1: 500$ & Cell Signaling, Danvers, MA, USA \\
Anti-PP2BC & rabbit, polyclonal & $1: 500$ & Abcam, Cambridge, UK \\
Anti-p21 & rabbit, polyclonal & $1: 800$ & Cell Signaling, Danvers, MA, USA \\
Anti-PCNA & rabbit, polyclonal & $1: 500$ & Cell Signaling, Danvers, MA, USA \\
Anti-cleaved-caspase3 & rabbit, polyclonal & $1: 500$ & Cell Signaling, Danvers, MA, USA \\
Anti-MMP9 & rabbit, polyclonal & $1: 600$ & Sigma-Aldrich, St. Louis, MO, USA \\
Anti-Col. I & rabbit, polyclonal & $1: 800$ & Sigma-Aldrich, St. Louis, MO, USA \\
Anti-actin & mouse, monoclonal & $1: 10000$ & Sigma-Aldrich, St. Louis, MO, USA \\
\hline
\end{tabular}

JNK, PP2A, PP2B, p21, PCNA, Cleaved caspase3, MMP9, collagen type I (Col. I), and actin. PhosphoSer/Thr detection kit (Millipore, Billerica, MA, USA) was used to detect phosphorylation level of Ser/Thr amino acid side chains. Proteins were blotted to nitrocellulose membranes and exposed to the primary antibodies overnight at $4{ }^{\circ} \mathrm{C}$ in the dilution as given in Table 2. Incubation was followed by $30 \mathrm{~min}$ PBST washing then membranes were covered with the peroxidase-conjugated secondary antibody antirabbit IgG in a 1:1500 (Bio-Rad Laboratories, CA, USA) or anti-mouse IgG in 1:1500 (Bio-Rad Laboratories, CA, USA) dilution. For detection enhanced chemiluminescence (Advansta Inc., Menlo Park, CA, USA) was used according to the instructions of the manufacturer. Actin was used as an internal control. Signals were captured with a cooled camera on gel documentary system (Fluorchem E, ProteinSimple, CA, USA). Optical densities of signals were measured by using ImageJ $1.40 \mathrm{~g}$ freeware. Before optical density measurements we made individual calibrations on every photomicrograph. Then we increased the magnification of the photos to reach individual pixel size and with freehanded method lanes were precisely circled and measured the integrated density of the area. The pixels were measured in 5 independent experiments by 3 independent operators. Signals first were compared with the WT actin for better comparison of expression differences in $\mathrm{AD}$ and TAD. Numbers below the lanes show the statistical analysis of the experiments where every separate experiment (at least 5) was normalized to its own actin signal and then statistical differences were calculated.

\section{Statistical analysis}

All data are representative of at least five independent experiments. For all figures the samples of the same WT, AD, and TAD animals were chosen with their inner control for better comparison. Only one demonstrative photo from the same animal group was used in every figure. Statistical analysis was performed by one-way analysis of variance (ANOVA), followed by Tukey's HSD post-hoc test. Threshold for statistically significant differences as compared to control samples was set at ${ }^{*} p<0.05$ and to AD samples ${ }^{\#} p<0.05$. ${ }^{*}$ indicates, the differences WT compared with $\mathrm{AD}$ and TAD, \# indicates the differences AD compared with TAD.

\section{RESULTS}

\section{Physical activity normalized the canonic TGF $\beta$ signaling pathway in kidneys of $A D$ mice}

Expression of the elements of canonical TGF $\beta$ signaling pathway was investigated in detail. Protein and mRNA expression of TGF $\beta 1$ did not show any significant difference when kidneys of WT and AD mice were compared but increased expression was found in TAD samples (Fig. 1A, B). Expression of TGFßRI reduced in $\mathrm{AD}$ but physical activity normalized it (Fig. 1A, B), while the expression of TGF $\beta$ RII elevated in kidneys of $\mathrm{AD}$ mice but diminished after physical activity (Fig. 1A, B). In line with these observations, the expression of Smad2 increased in $\mathrm{AD}$ samples and it was normalized after physical 
A. RT-PCR

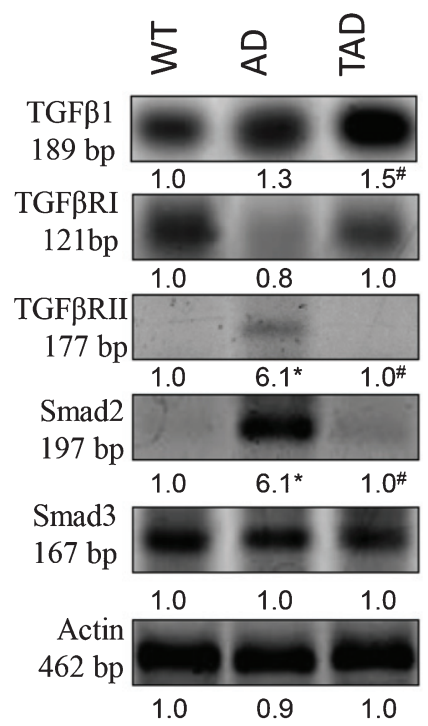

\section{B. Western blot}

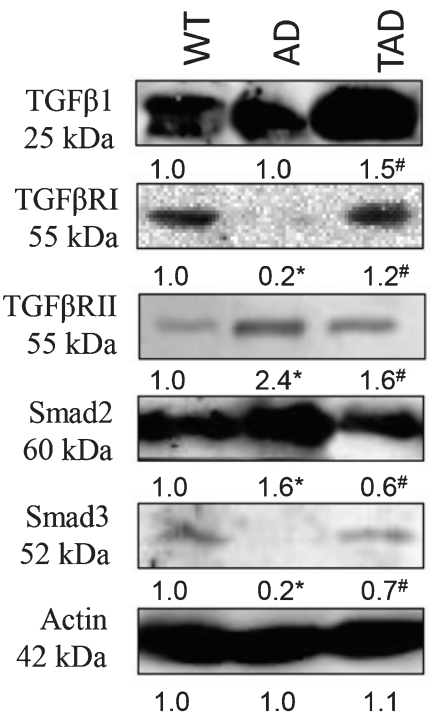

C. Smad2 immunohistochemistry
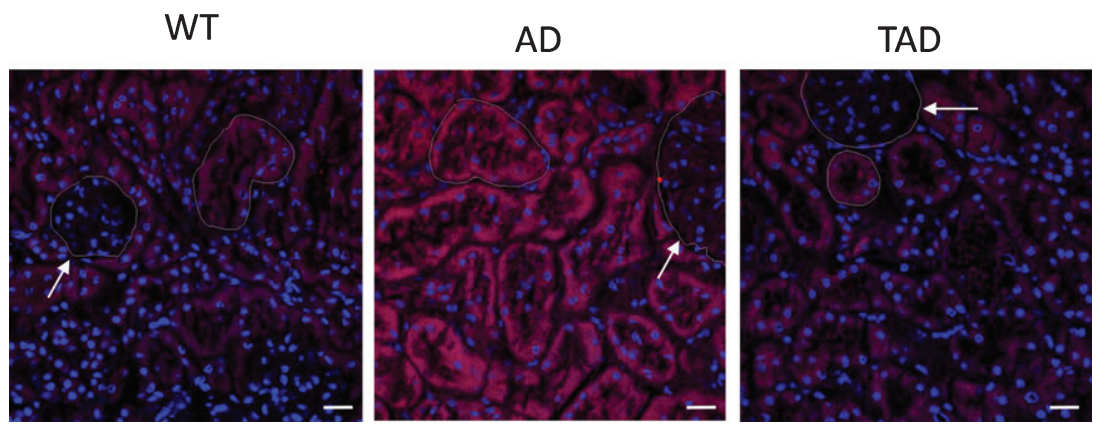

Fig. 1. mRNA (A) and protein (B) expression of canonical TGF $\beta$ signaling elements in the kidney. Optical density of signals was measured, and results were normalized to the optical density of wild type (WT). For panels A and B, numbers below the signals represent integrated densities of signals determined by ImageJ software. Asterisks indicate significant alteration of expression as compared to WT $\left({ }^{*} p<0.05\right)$ or Alzheimer's disease (AD) mice ( $\left.{ }^{*} p<0.05\right)$. Representative data of five independent experiments. For RT-PCR reactions and for western blot actin was used as controls. Statistical analysis was performed by ANOVA. All data were normalized to actin and data are expressed as mean \pm SEM. (C) Immunohistochemistry of Smad2 in renal cortex. Arrows point at renal corpuscules. Magnification was made with $60 \times$ objective. Scale bar: $20 \mu \mathrm{m}$.

activity (Fig. 1A, B). On the contrary, the expression of Smad3 showed a moderate decrease in kidneys of AD mice which was compensated in TAD samples (Fig. 1A, B). Elevation of Smad2 positive signals was seen in the tubular system of the cortex but not in the renal corpuscles in AD mice. This elevation was reduced in tubules of TAD animals (Fig. 1C).

\section{Non-canonical signaling pathways were modified in kidneys of $A D$ mice after physical activity}

MAPK-es, such as ERK, p38, and JNK, form an important part of non-canonical TGF $\beta$ signaling [22]. mRNA expression of ERK was not altered in kidneys of $\mathrm{AD}$ mice but showed a decrease in TAD samples (Fig. 2A). Protein expression of this kinase was not in correlation with the mRNA expression and a strong reduction was detected in kidneys of $\mathrm{AD}$ mice with a moderate normalization after increased physical activity (Fig. 2B). The active, phosphorylated form interestingly elevated in AD samples and showed a similar decrease in kidneys of TAD mice (Fig. 2B). mRNA expression of p38 was not altered significantly in any samples (Fig. 2A). Protein expression of p38 strongly increased in kidneys of AD mice which was partly compensated by physical activity (Fig. 2B). Interestingly the more active phosphorylated form showed a reduction in $\mathrm{AD}$ samples which 
A. RT-PCR

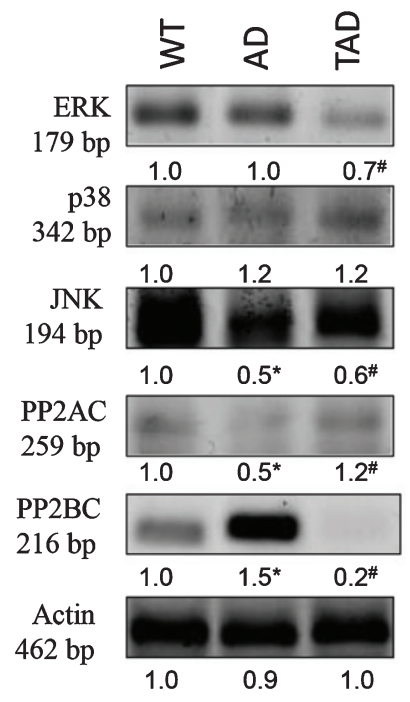

C. Phospho Ser/Thr detection
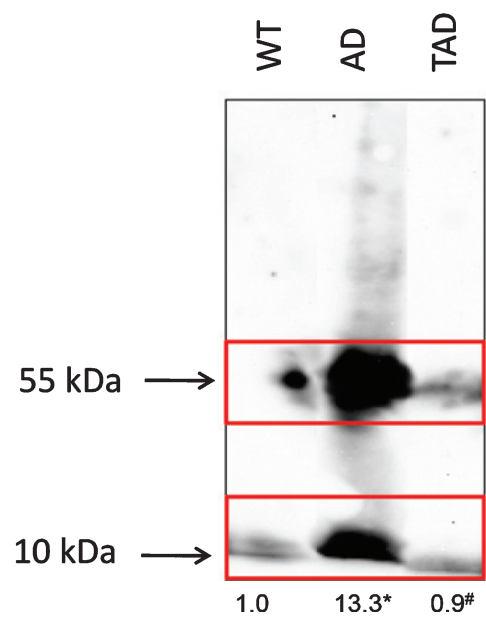

B. Western blot

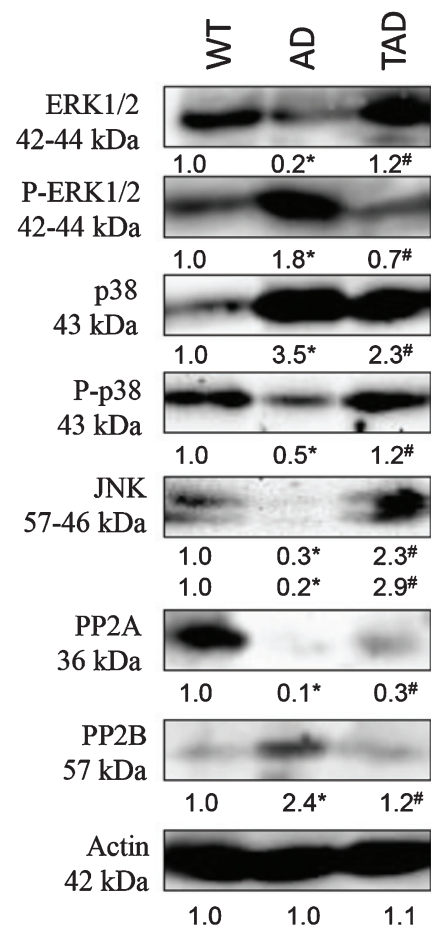

Fig. 2. mRNA (A) and protein (B) expression of non-canonical signaling elements of TGF $\beta$ pathways in the kidney. For RT-PCR and for western blot reactions, actin was used as control. C) Ser/Thr phosphorylation was investigated by western blot analysis. Insert represents the molecular weight approximately 55 and $10 \mathrm{kDa}$. Optical density of signals was measured and results were normalized to the optical density of controls. For panels A-C, numbers below the signals represent integrated densities of signals determined by ImageJ software. Asterisks indicate significant alteration of expression as compared to wild type (WT) $\left({ }^{*} p<0.05\right)$ or Alzheimer's disease (AD) mice $\left({ }^{\#} p<0.05\right)$. Representative data of five independent experiments. For RT-PCR reactions and for western blot actin was used as controls. Statistical analysis was performed by ANOVA. All data were normalized to actin and data are expressed as mean \pm SEM.

was normalized in TAD animals (Fig. 2B). mRNA expression of JNK was reduced both in $\mathrm{AD}$ and TAD samples (Fig. 2A). Protein expression of the 2 isoforms of JNK was detected by western blot analysis. Non-redundant functions for JNK1 and JNK2 have been revealed [34] and it was detected a significant decrease of $57 \mathrm{kDa}$ isoform and of $46 \mathrm{kDa}$ isoform in AD samples (Fig. 2B). $57 \mathrm{kDa}$ and $46 \mathrm{kDa}$ isoforms showed an elevation after physical activity in kidneys of TAD mice (Fig. 2B).

\section{Altered expression of Ser/Thr phosphatases and modified protein phosphorylation in $A D$}

Altered Ser/Thr specific protein phosphatase expression and function has been demonstrated in AD $[35,36]$. We detected an increased expression of PP2B in kidneys of AD mice, but it was reduced by physical activity (Fig. 2A, B). On the contrary, the expression of the other major cellular Ser/Thr specific phosphatase, PP2A, appeared with a strong reduction 
A. RT-PCR

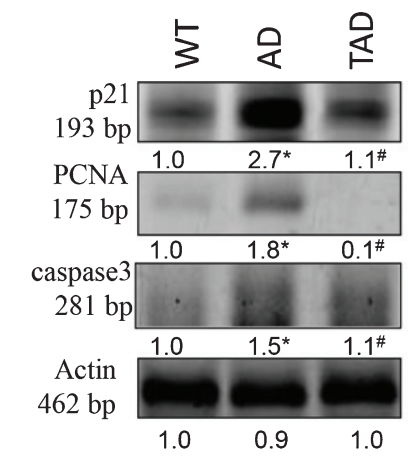

C. PCNA immunohistochemistry

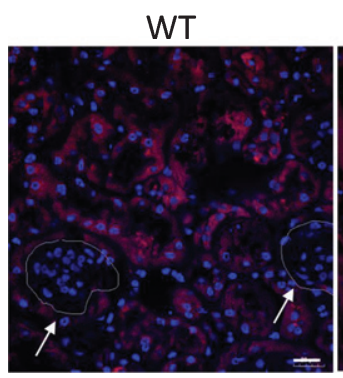

B. Western blot

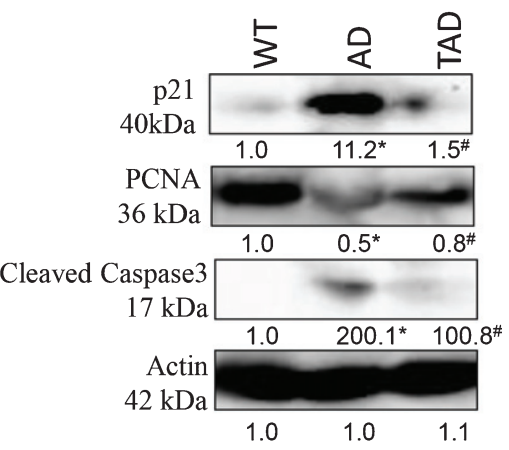

TAD
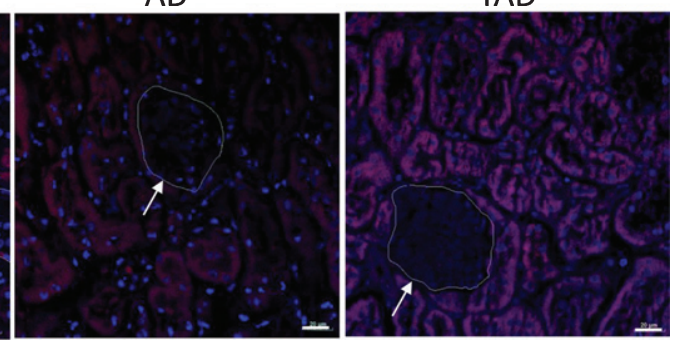

Fig. 3. mRNA (A) and protein (B) expression of canonical p21, PCNA and caspase 3 in the kidney. Optical density of signals was measured, and results were normalized to the optical density of wild type (WT). For panels A and B, numbers below the signals represent integrated densities of signals determined by ImageJ software. Asterisks indicate significant alteration of expression as compared to WT $\left({ }^{*} p<0.05\right)$ or Alzheimer's disease (AD) mice $\left({ }^{\#} p<0.05\right)$. Representative data of five independent experiments. For RT-PCR reactions and for western blot actin was used as controls. Statistical analysis was performed by ANOVA. All data were normalized to actin and data are expressed as mean \pm SEM. C) Immunohistochemistry of PCNA in renal cortex. Arrows point at renal corpuscules. Magnification was made with $60 \times$ objective. Scale bar: $20 \mu \mathrm{m}$.

in kidneys of AD mice (Fig. 2A, B). In TAD samples, mRNA and protein expression of PP2A catalytic subunit increased (Fig. 2A, B). Investigation of protein phosphorylation on Ser/Thr residues showed a strong signal at $55 \mathrm{kDa}$ in kidneys of AD mice, representing the molecular weight of tau (Fig. 2C). Another elevated band appeared at $10 \mathrm{kDa}$ which corresponds to the molecular weight of the cleaved C-terminal of A $\beta P P$ (Fig. 2C). The phosphorylation of both of these proteins reduced upon exercising (Fig. 2C).

\section{TGF $\beta$ signaling affected cell cycle and apoptosis}

As markers of cell proliferation p21 and PCNA expression levels were monitored. TGF $\beta$ activation is known to induce the expression of p21 [37]. Furthermore, TGF $\beta 1$ activation results an altered cell proliferation [38]. Therefore, proliferating cell nuclear antigen (PCNA) expression was investigated. The protein level of p21 was significantly elevated in AD but was reduced in TAD samples (Fig. 3A, B). PCNA responded differently: AD caused reduction in protein expression, while PCNA protein increased upon exercising (Fig. 3A, B). Immunohistochemistry was performed to identify PCNA positive cells and resulted in reduced immunoreactivity in tubular cells in kidneys of AD mice. Interestingly a normalized PCNA positivity was shown in the tubular cells in TAD mice. No PCNA positive cells were detected in renal corpuscles (Fig. 3C). As TGF $\beta 1$ signaling can affect apoptosis [39], the active form of proapoptotic caspase 3 was investigated. Although a slight mRNA expression of caspase 3 was detected in WT samples, no cleaved, active capase 3 was shown. On the contrary, a strong mRNA and cleaved caspase 3 appeared in $\mathrm{AD}$ samples, while increased physical activity reduced the expression of the proapoptotic protein (Fig. 3A, B).

\section{Kidney fibrosis was downregulated by physical activity}

Previous results indicate a possible fibrosis in kidneys of AD animals. First, MMP9 expression, which 
can be regulated via TGF $\beta 1$ activation, was investigated [21]. mRNA of MMP9 was expressed in all samples but showed a significant increase only in kidneys of TAD mice. Protein expression of the matrix metalloproteinase was at the detection limit in WT samples but showed a significant elevation in AD animals. Surprisingly, active physical exercise dramatically increased MMP9 expression (Fig. 4A, B). The other component of fibrotic processes is the increased deposition of collagen type I in the kidney [40]. In WT samples, low mRNA and protein expression of collagen type I were detected but a strong increase was shown in AD animals. Active physical movement normalized both the mRNA and protein expression of collagen type I (Fig. 4A, B). Collagen type I normally surrounds the tubules and is localized also in the interstitium. With routine pathohistological staining of Masson's trichrome, blue color represents the presence of any type of collagen, which was visible around the tubules, renal corpuscles, and a small amount in the interstitium in WT kidneys. In AD samples, a strong accumulation was visible in the interstitium and in some tubules. After physical activity, the amount of collagen was reduced, and no accumulation was detected in the interstitium (Fig. 4C). Collagen type I immunohistochemistry was performed to specify the accumulated collagen. In WT kidneys, similarly to Masson's staining, signals appeared around the tubules, renal corpuscles and a weak interstitial signal was also visible. In samples from AD mice, a strong immunopositivity was shown in the interstitium and around the tubular system. Surprisingly, a reduction was visible in the interstitial tissue, but a significant signal appeared in the apical part of the tubuloepithelial cells in TAD animals (Fig. 4D).

\section{DISCUSSION}

Although the process of AD formation is broadly discussed in CNS, alterations and possible peripheral accompanying pathologies are not investigated in detail. Our major hypothesis was that kidney fibrosis is a possible process which affects $\mathrm{AD}$ manifestation and $A \beta$ accumulation. On the other hand, longterm physical training has a positive effect on $\mathrm{AD}$ which may have correlation with the systemic alteration TGF $\beta$ signaling pathway. Peripheral organs have been demonstrated to be involved in AD pathogenesis, as among others, altered metabolic enzyme activity has been detected in $A D$ patients [41] and $A \beta$ accumulation has been shown in the pancreas [42] and in the kidney [30]. This systemic illness affecting various organs makes $\mathrm{AD}$ early diagnosis and curability difficult. Clearance of $A \beta$ from the CNS is partly regulated by astrocytes and microglia but some portion after passing through the blood-brain barrier can be removed in the periphery [43]. This peripheral clearance is considered as one of the possible drug targets to reduce $A \beta$ concentration in the plasma [44]. The secretion of small molecules by the proximal tubules of the kidneys represents a vital homeostatic function and may take part in the secretion of toxins or proteins into the urine [45]. It has been demonstrated that $A \beta$ is secreted in urine and can be a diagnostic sign of dementia [46]; additionally, kidney dysfunction in the elderly can elevate the risk of dementia [47], and it was found that serum $A \beta$ levels were significantly higher in CKD patients [10]. These data indicate a possible function of kidney in $A \beta$ clearance in the periphery. Physical exercise has been shown to have positive effects on kidney function as it preserved proper glomerular morphology and protected the tubular secretion [48]. Increased physical activity has been shown to decrease the TGF $\beta$ signalization in kidneys and physical exercise can be a good antifibrotic strategy [32]. Altogether, TGF $\beta$ activation may have a direct connection to physical activity-related signaling which may maintain the $A \beta$ clearance in the periphery. Therefore, we investigated TGF $\beta$ signaling pathway in WT, AD, and long-term trained AD mice.

In the current study, it was demonstrated that TGF $\beta$ RII expression was increased in kidneys of AD mice and partially normalized in TAD samples. The elevated TGF $\beta$ RII indicates an enhanced activation of TGF $\beta$ signaling pathway in AD [49]. The decreased TGF $\beta R I$ expression showed that TGF $\beta 1$ binds with higher affinity to TGF $\beta$ RII and homodimer formation is likely in AD [50]. Similarly to these results, TGFßRII homodimer formation has been shown in macrophages in renal fibrosis [51]. On the other hand, long-term training equalized the expression of TGF $\beta$ receptors suggesting a heterodimer receptor complex formation which can be stabilized by the elevated TGF $\beta 1$ expression [50]. Moreover, Smad2 and Smad3 expression was altered controversially in AD. Smad2 is known to be activated classically by TGF $\beta$ receptors and translocated into the nucleus while Smad3 has a distinct function [52]. It has been published that Smad3 down-regulation affects fibrosis [53]. The normalized expression of Smad transcription factors in TAD samples indicates 
A. RT-PCR

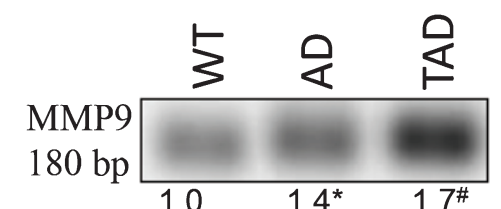

Colla1

$190 \mathrm{bp}$

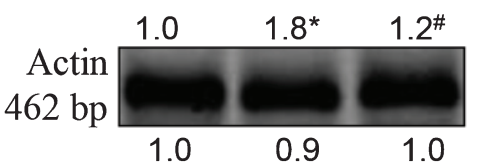

B. Western blot
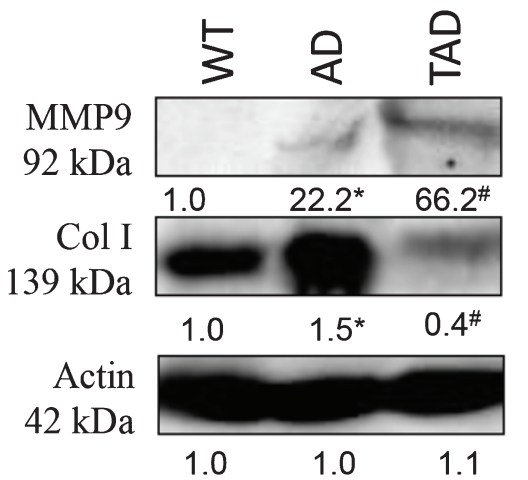

C. Masson's trichrome staining

WT

$A D$

TAD

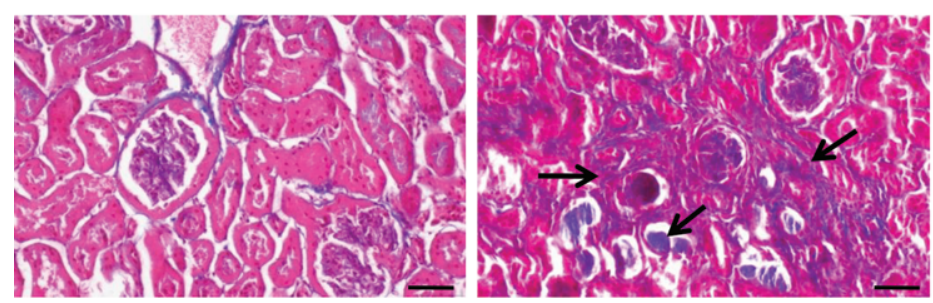

\section{Collagen type I immunohistochemistry}
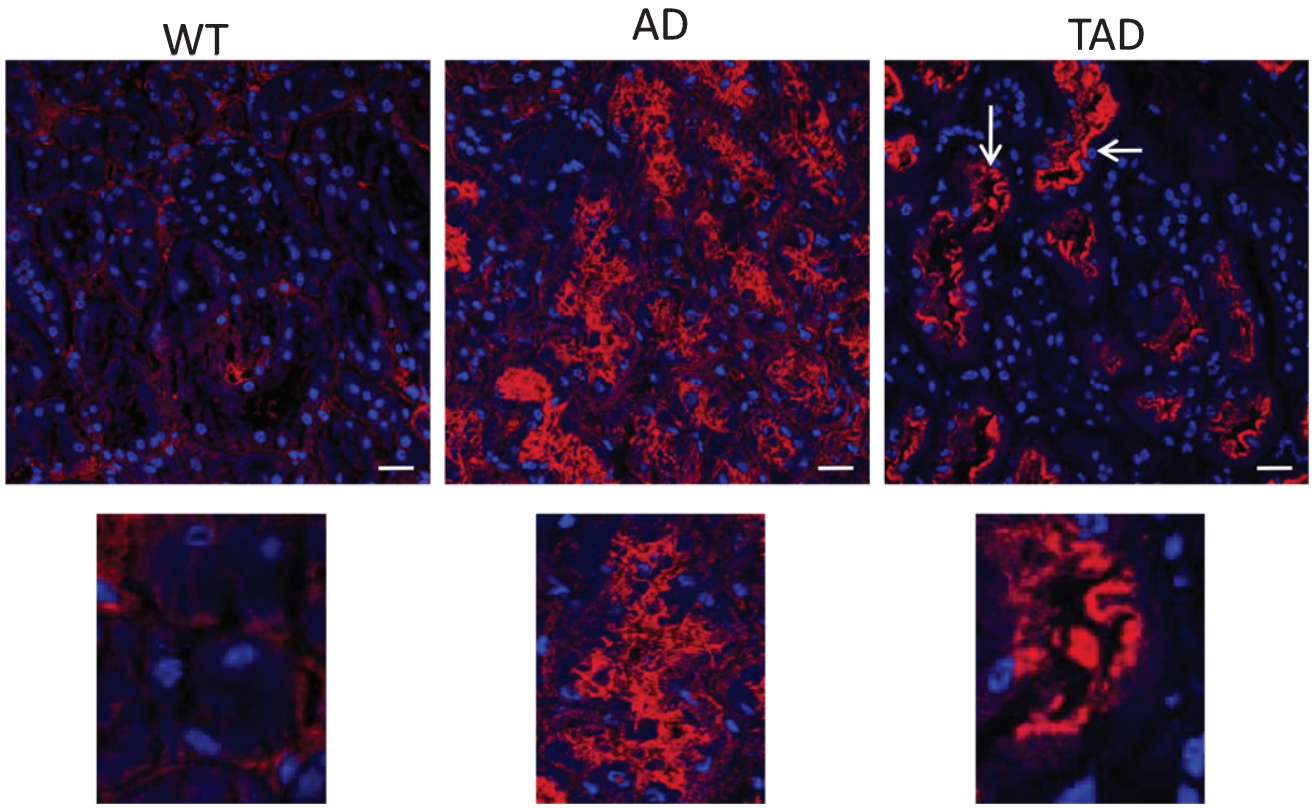

Fig. 4. mRNA (A) and protein (B) expression of collagen type I (Col. I) and MMP9 in the kidney. Optical density of signals was measured and results were normalized to the optical density of wild type (WT). For panels A and B, numbers below the signals represent integrated densities of signals determined by ImageJ software. Asterisks indicate significant alteration of expression as compared to WT $\left({ }^{*} p<0.05\right)$ or Alzheimer's disease (AD) mice $\left({ }^{\#} p<0.05\right)$. Representative data of five independent experiments. For RT-PCR reactions and for western blot actin was used as controls. Statistical analysis was performed by ANOVA. All data were normalized to actin and data are expressed as mean \pm SEM. C) Representative microphotograph of WT, AD, and trained AD (TAD) kidneys stained with Masson's trichrome. Overview of kidney cortex. Original magnification was $20 \times$. Scale bar: $50 \mu \mathrm{m}$. Arrows show a representative area for fibrotic tissue formation. D) Immunohistochemistry of collagen type I in renal cortex. Magnification was made with $60 \times$ objective. Scale bar: $20 \mu \mathrm{m}$. 
that physical activity re-balanced TGF $\beta$ signaling and reduced its pathobiochemical activation.

The mitogen-activated protein kinase (MAPK) family containing p38MAPK, JNK, and ERK has an interaction with TGF $\beta$ signalization [54]. Elevated expression of $\mathrm{p} 38$ has been shown in tubular epithelial cells inducing kidney fibrosis and its blocking can be a good target of fibrosis treatment [55]. In $\mathrm{AD}$ mice increased $\mathrm{p} 38$ protein expression was detected which further supports fibrosis formation. On the contrary, p38 phosphorylation was reduced in AD kidney indicating a fibrosis stage dependent activation of p38 MAPK [56]. On the other hand, elevated physical activity partially normalized both the p38 and phosphorylated form present in the kidney suggesting a balancing function of training in p38-mediated fibrosis formation. Similarly to p38 kinase, inhibition of JNK can suppress fibrosis formation [57]. JNK activation has various functions in different parts of the kidney, such as glomerular filtration and interstitial fibrotic processes [58]. The protein extract in our experiments derived from total kidney lysate indicating that during AD development JNK has likely a distinct function in the tubular and glomerular parts with cell specific isotype activation in AD-affected kidneys. TGF $\beta 1$ induced MMP activation was reported depending on $\mathrm{p} 38$ function [59], while the inhibition of ERK activity reduced interstitial fibrosis [60]. These data strongly support distinct functions of the MAPK family members in the pathogenesis of kidney fibrosis in AD. We detected a low ERK expression in kidneys of AD mice, while the amount of its phosphorylated, active form significantly elevated. In the experimental group of mice taking part in long-term physical training, we detected normalized ERK and phospho-ERK expression and a beneficial effect on renal function. These observations support contribution of ERK in the fibrotic transformation of kidneys in $\mathrm{AD}$ and demonstrate a surprisingly obvious positive influence of physical training on kidney's morphology and function of AD mice. Recently, our laboratory has proven the involvement of ERK in mechanotransduction of developing cartilage cells [61].

TGFßRII, Smad, JNK, p38, and ERK phosphorylation occur on Ser residues [62] which propose a possible activation of Ser/Thr phosphatases. PP2B dysregulation has been demonstrated in $\mathrm{AD}[35,63]$. On the other hand, PP2B does not significantly regulate phosphorylation of tau in the brain, although it is able to dephosphorylate it at several phosphorylation sites [35]. The other major cellular Ser/Thr phosphatase, PP2A also dephosphorylates proteins on Ser residues and its activity is reduced in $\mathrm{AD}$ and it is able to regulate tau phosphorylation with higher affinity than PP2B [64]. A reduced PP2A, but an increased PP2B expression in kidneys of AD mice was demonstrated, similarly to the CNS. Increased phosphorylation on Ser residues, as the result of PP2A expression decrease, can induce the hyperphosphorylation of tau protein or A $\beta P P$ as it was predicted in kidneys of AD mice. Dephosphorylation of JNK and p38 can be directly regulated by PP2B [65], therefore, the decreased activation of these kinases in $\mathrm{AD}$ can be the consequence of elevated PP2B expression. On the other hand, ERK kinase dephosphorylation can happen dominantly through PP2A activation [66], subsequently reduced expression of PP2A can lead to an increased ERK phosphorylation in $\mathrm{AD}$. Long-term training of $\mathrm{AD}$ mice acted toward the normalization of PP2B and PP2A expression which in turn seemed to shift the Ser/Thr phosphorylation level of MAPK enzymes closer to the normal. Mechanical load exerted balancing effect on reversible phosphorylation through the involvement of PP2B and PP2A in differentiating chondrocytes as well [61].

Activation of non-canonical TGF $\beta$ signaling pathway regulates cellular proliferation and apoptosis. Similarly to our results, p21 positive cells have been shown in the tubular system of the kidney [67], and we also demonstrated their increased expression in AD. This elevation suggests a cell cycle arrest in AD mediated by MAPK activation, while p21 interacts with PCNA and blocks cells in S-phase of cell cycle [68]. We detected $\mathrm{p} 21$ activation and a probably consequent strong PCNA reduction in the tubular system of AD mice. Similarly to our previous findings, enhanced physical activity normalized the cell cycle in the cells of the tubular system. On the other hand, p21 also has a connection with caspase activation and JNK, while ERK also induces caspase 3 cleavage [69, 70]. Caspase 3 activation has been identified to play an important role in $\mathrm{AD}$ pathogenesis via $\mathrm{A} \beta$ accumulation and caspase mediated $A \beta P P$ cleavage induced synaptical disorders [71]. In kidneys of AD mice, we detected high cleaved caspase 3 expression indicating an elevated apoptosis and the loss of function of tubular and glomerular cells. These processes can promote accumulation of $A \beta$ in the kidney interstitium as we have shown earlier [30].

TGF $\beta$ mediated signalization has been shown to increase collagen expression and accumulation in the interstitium [40]. According to these results in 
kidneys of AD mice, we demonstrated a significantly elevated collagen type I expression accumulated in the interstitium. These data strongly suggest that altered canonical and non-canonical TGF $\beta$ signalization in AD plays a crucial role in kidney fibrosis $[18,72]$. On the contrary, long-term training reduced the interstitial collagen type I localization at least partly through re-balancing the TGF $\beta$ signalization. Reduced fibrosis can induce $A \beta$ clearance and decrease its renal accumulation as we have demonstrated earlier [30]. This hypothesis was supported by our finding, as physical training resulted in accumulation of collagen type I in tubular epithelial cells, which was demonstrated in kidneys of TAD mice implying collagen degradation process. MMP9 can be activated by TGF $\beta$ signaling in the kidney [73] and results in the degradation of matrix fibrils. Although MMPs have both inhibitory and stimulatory roles in fibrosis, MMP9 is considered as a profibrotic agent mediated by TGF $\beta$ activation [74]. On the contrary, it has been demonstrated that MMP9 can play a regulatory role in collagen type I degradation in the kidney [75]. In kidneys of AD mice, we showed an elevated MMP9 expression suggesting its function in fibrotic process controlled by TGF $\beta$ signaling cascade. On the other hand, further elevation was measured after long-term training which can be the reason of strong reduction in expression and tubular appearance of collagen type I. In mechanical stimulus, our laboratory has shown that MMP9 expression was elevated in primary chondrogenic cultures [76], and similar results have been published in scar tissue formation where mechanical compression increased the expression of MMP9 [77]. In acute kidney injury, elevation of MMP9 has anti-apoptotic function and protect the S3 part of proximal tubules [78]. Furthermore, shear stress activated TGF $\beta$ signaling pathway and decreased fibrosis formation has also been detected in the lungs [79]. Moreover, mechanical stress in lung epithelial cells induced the remodeling of ECM via the activation of MMP9 and alter collagen expression [80]. Therefore, we can conclude that increased physical activity induces the remodeling of matrix production via modulating TGF $\beta$ signalization not only locally but also systemically as well.

The limitations of our work are that transgenic mice may have a quicker $\mathrm{AD}$ formation and kidney function is not investigated in detail. It has to be further investigated that only the TGF $\beta$ induced matrix production is altered in fibrotic kidneys of $A D$ mice or the regulation of sodium and potassium balance and $A \beta$ clearance are also involved in long-term training. In addition, accumulation of collagen type I in the urine can also be followed further to improve that long-term physical training in $\mathrm{AD}$ leads to the reduction of kidney fibrosis.

On the other hand, we proved in vivo that long-term physical training has a systemic effect on canonical and non-canonical TGF $\beta$ signaling. In vivo we demonstrated that physical training reduced the formation of kidney fibrosis in AD which has a positive effect on manifestation of the illness.

In conclusion, our data suggest that the activation of TGF $\beta$ signaling pathways plays a causative role in the fibrotic transformation of kidneys of AD mice. As a very simple approach to achieve positive changes in this condition, we recommend long-term physical training, as it was able to normalize the expression and phosphorylation of members of canonical and non-canonical TGF $\beta$ signaling pathways and resulted in improvement of kidney fibrosis. Moreover, physical exercise inhibiting the fibrosis can re-balance the kidney function and can induce an elevated clearance of systemic $A \beta$ in $A D$.

\section{ACKNOWLEDGMENTS}

The authors are grateful for Mrs. Krisztina Bíró for excellent technical assistance. NKFIK115874, K135457, K119759, NKFIHFK129190, PTE AOK Research Grant 2017-03, MTA-TKI 14016, GINOP2.3.2-15-2016-00050 "PEPSYS", New National Excellence Program of the Ministry of Human Capacities (UNKP-16-4-IV.), EFOP-3.6.1.-16-201600004 Comprehensive Development for Implementing Smart Specialization Strategies at the University of Pecs, EFOP-3.6.2-16-2017-00008 "The role of neuro-inflammation in neurodegeneration: from molecules to clinics" Centre for Neuroscience of the University of Pecs, EFOP-3.6.3-VEKOP-16-201700009, University of Debrecen (OTKA Bridging Fund), EFOP-3.6.1.-16-2016-00004 Comprehensive Development for Implementing Smart Specialization Strategies at the University of Pécs (Budapest, Hungary), NAP 2017-1.2.1-NKP-2017-00002 and OTKA-NN 114458. The project is co-financed by the European Union and the European Social Fund. Bolyai Janos Research Scholarship (A.T.). Szodoray Lajos and Magyary Zoltán Funds by Hungarian Academy of Science and the European Union and the State of Hungary, co-financed by the European Social Funding. Fund in the framework of TÁMOP 4.2 .4 (J.T.). Sz.V. is supported by the 
ÚNKP-19-3 "National Excellence Program" of the Ministry of Human Capacities. A/2-11-1-2012-0001 "National Excellence Program". Higher Education Institutional Excellence Program of the Ministry of Human Capacities in Hungary, within the framework of the FIKP III (2019) of the University of Pécs and Z.R. by National Excellence Program (126823) of Innovation and Technology Ministry, Hungary.

Authors' disclosures available online (https:// www.j-alz.com/manuscript-disclosures/20-1206r2).

\section{REFERENCES}

[1] Belghali M, Chastan N, Cignetti F, Davenne D, Decker LM (2017) Loss of gait control assessed by cognitive-motor dual-tasks: Pros and cons in detecting people at risk of developing Alzheimer's and Parkinson's diseases. Geroscience 39, 305-329.

[2] Pomilio C, Gorojod RM, Riudavets M, Vinuesa A, Presa J, Gregosa A, Bentivegna M, Alaimo A, Alcon SP, Sevlever G, Kotler ML, Beauquis J, Saravia F (2020) Microglial autophagy is impaired by prolonged exposure to betaamyloid peptides: Evidence from experimental models and Alzheimer's disease patients. Geroscience 42, 613-632.

[3] Reglodi D, Jungling A, Longuespee R, Kriegsmann J, Casadonte R, Kriegsmann M, Juhasz T, Bardosi S, Tamas A, Fulop BD, Kovacs K, Nagy Z, Sparks J, Miseta A, Mazzucchelli G, Hashimoto H, Bardosi A (2018) Accelerated pre-senile systemic amyloidosis in PACAP knockout mice - a protective role of PACAP in age-related degenerative processes. J Pathol 245, 478-490.

[4] Turner RS, Stubbs T, Davies DA, Albensi BC (2020) Potential new approaches for diagnosis of Alzheimer's disease and related dementias. Front Neurol 11, 496.

[5] Tavares RS, Martins S, Almeida-Santos T, Sousa AP, Ramalho-Santos J, da Cruz ESOA (2017) Alzheimer's disease-related amyloid-beta1-42 peptide induces the loss of human sperm function. Cell Tissue Res 369, 647-651.

[6] Kulas JA, Puig KL, Combs CK (2017) Amyloid precursor protein in pancreatic islets. $J$ Endocrinol 235, 49-67.

[7] Paterson EN, Williams MA, Passmore P, Silvestri G, MacGillivray TJ, Maxwell AP, McKay GJ (2017) Estimated glomerular filtration rate is not associated with Alzheimer's disease in a Northern Ireland cohort. J Alzheimers Dis 60 , 1379-1385.

[8] Morris JK, Honea RA, Vidoni ED, Swerdlow RH, Burns JM (2014) Is Alzheimer's disease a systemic disease? Biochim Biophys Acta 1842, 1340-1349.

[9] Ghiso J, Calero M, Matsubara E, Governale S, Chuba J, Beavis R, Wisniewski T, Frangione B (1997) Alzheimer's soluble amyloid beta is a normal component of human urine. FEBS Lett 408, 105-108.

[10] Liu YH, Xiang Y, Wang YR, Jiao SS, Wang QH, Bu XL, Zhu C, Yao XQ, Giunta B, Tan J, Zhou HD, Wang YJ (2015) Association between serum amyloid-beta and renal functions: Implications for roles of kidney in amyloid-beta clearance. Mol Neurobiol 52, 115-119.

[11] Sakai K, Senda T, Hata R, Kuroda M, Hasegawa M, Kato M, Abe M, Kawaguchi K, Nakai S, Hiki Y, Yuzawa Y, Kitaguchi N (2016) Patients that have undergone hemodialysis exhibit lower amyloid deposition in the brain: Evidence supporting a therapeutic strategy for Alzheimer's disease by removal of blood amyloid. J Alzheimers Dis 51, 997-1002.

[12] Gronewold J, Todica O, Klafki HW, Seidel UK, Kaltwasser B, Wiltfang J, Kribben A, Bruck H, Hermann DM (2017) Association of plasma beta-amyloid with cognitive performance and decline in chronic kidney disease. Mol Neurobiol 54, 7194-7203.

[13] Gu YY, Liu XS, Huang XR, Yu XQ, Lan HY (2020) Diverse role of TGF-beta in kidney disease. Front Cell Dev Biol $8,123$.

[14] Grammas P, Ovase R (2002) Cerebrovascular transforming growth factor-beta contributes to inflammation in the Alzheimer's disease brain. Am J Pathol 160, 1583-1587.

[15] von Bernhardi R, Eugenin-von Bernhardi L, Eugenin J (2015) Microglial cell dysregulation in brain aging and neurodegeneration. Front Aging Neurosci 7, 124.

[16] Bisht K, Sharma K, Tremblay ME (2018) Chronic stress as a risk factor for Alzheimer's disease: Roles of microgliamediated synaptic remodeling, inflammation, and oxidative stress. Neurobiol Stress 9, 9-21.

[17] Lian H, Zheng H (2016) Signaling pathways regulating neuron-glia interaction and their implications in Alzheimer's disease. J Neurochem 136, 475-491.

[18] Kajdaniuk D, Marek B, Borgiel-Marek H, Kos-Kudla B (2013) Transforming growth factor beta1 (TGFbeta1) in physiology and pathology. Endokrynol Pol 64, 384-396.

[19] Shi Y, Chen X, Huang C, Pollock C (2020) RIPK3: A new player in renal fibrosis. Front Cell Dev Biol 8, 502.

[20] Tzavlaki K, Moustakas A (2020) TGF-beta Signaling. Biomolecules 10, 487.

[21] Zhao H, Dong Y, Tian X, Tan TK, Liu Z, Zhao Y, Zhang Y, Harris D, Zheng G (2013) Matrix metalloproteinases contribute to kidney fibrosis in chronic kidney diseases. World J Nephrol 2, 84-89.

[22] Mulder KM (2000) Role of Ras and Mapks in TGFbeta signaling. Cytokine Growth Factor Rev 11, 23-35.

[23] Meng XM, Ren GL, Gao L, Li HD, Wu WF, Li XF, Xu T, Wang XF, Ma TT, Li Z, Huang C, Huang Y, Zhang L, Lv XW, Li J (2016) Anti-fibrotic effect of wogonin in renal tubular epithelial cells via Smad3-dependent mechanisms. Eur J Pharmacol 789, 134-143.

[24] Stojanovic M, Jin Y, Fagan AM, Benzinger TL, Hassenstab J, Cruchaga C, Morris JC, Head D (2020) Physical exercise and longitudinal trajectories in Alzheimer disease biomarkers and cognitive functioning. Alzheimer Dis Assoc Disord 34, 212-219.

[25] Valenzuela PL, Castillo-Garcia A, Morales JS, de la Villa P, Hampel H, Emanuele E, Lista S, Lucia A (2020) Exercise benefits on Alzheimer's disease: State-of-the-science. Ageing Res Rev 62, 101108.

[26] de Frutos-Lucas J, Cuesta P, Lopez-Sanz D, Peral-Suarez A, Cuadrado-Soto E, Ramirez-Torano F, Brown BM, Serrano JM, Laws SM, Rodriguez-Rojo IC, Verdejo-Roman J, Bruna R, Delgado-Losada ML, Barabash A, LopezSobaler AM, Lopez-Higes R, Marcos A, Maestu F (2020) The relationship between physical activity, apolipoprotein E epsilon4 carriage, and brain health. Alzheimers Res Ther 12, 48.

[27] Meng Q, Lin MS, Tzeng IS (2020) Relationship between exercise and Alzheimer's disease: A narrative literature review. Front Neurosci 14, 131.

[28] Abraham D, Feher J, Scuderi GL, Szabo D, Dobolyi A, Cservenak M, Juhasz J, Ligeti B, Pongor S, Gomez-Cabrera MC, Vina J, Higuchi M, Suzuki K, Boldogh I, Radak Z (2019) Exercise and probiotics attenuate the development 
of Alzheimer's disease in transgenic mice: Role of microbiome. Exp Gerontol 115, 122-131.

[29] Radak Z, Hart N, Sarga L, Koltai E, Atalay M, Ohno H, Boldogh I (2010) Exercise plays a preventive role against Alzheimer's disease. J Alzheimers Dis 20, 777-783.

[30] Perenyi H, Szegeczki V, Horvath G, Hinnah B, Tamas A, Radak Z, Abraham D, Zakany R, Reglodi D, Juhasz T (2020) Physical activity protects the pathological alterations of Alzheimer's disease kidneys via the activation of PACAP and BMP signaling pathways. Front Cell Neurosci 14, 243.

[31] Szegeczki V, Horvath G, Perenyi H, Tamas A, Radak Z, Abraham D, Zakany R, Reglodi D, Juhasz T (2020) Alzheimer's disease mouse as a model of testis degeneration. Int J Mol Sci 21.

[32] Huang C, Lin YY, Yang AL, Kuo TW, Kuo CH, Lee SD (2018) Anti-renal fibrotic effect of exercise training in hypertension. Int J Mol Sci 19, 613.

[33] Iwasaki Y, Yamato H, Fukagawa M (2018) TGF-beta signaling in bone with chronic kidney disease. Int J Mol Sci 19, 2352.

[34] Bogoyevitch MA, Ngoei KR, Zhao TT, Yeap YY, Ng DC (2010) c-Jun N-terminal kinase (JNK) signaling: Recent advances and challenges. Biochim Biophys Acta 1804, 463-475.

[35] Qian W, Yin X, Hu W, Shi J, Gu J, Grundke-Iqbal I, Iqbal K, Gong CX, Liu F (2011) Activation of protein phosphatase 2B and hyperphosphorylation of tau in Alzheimer's disease. J Alzheimers Dis 23, 617-627.

[36] Leong W, Xu W, Wang B, Gao S, Zhai X, Wang C, Gilson E, Ye J, Lu Y (2020) PP2A subunit PPP2R2C is downregulated in the brains of Alzheimer's transgenic mice. Aging (Albany NY) 12, 6880-6890.

[37] Dattaroy D, Seth RK, Sarkar S, Kimono D, Albadrani M, Chandrashekaran V, Hasson FA, Singh UP, Fan D, Nagarkatti M, Nagarkatti P, Diehl AM, Chatterjee S (2018) Sparstolonin B (SsnB) attenuates liver fibrosis via a parallel conjugate pathway involving P53-P21 axis, TGF-beta signaling and focal adhesion that is TLR4 dependent. Eur $J$ Pharmacol 841, 33-48.

[38] Liu Y, Shang D (2020) Transforming growth factorbeta1 enhances proliferative and metastatic potential by up-regulating lymphoid enhancer-binding factor 1/integrin alphaMbeta2 in human renal cell carcinoma. Mol Cell Biochem 465, 165-174.

[39] Sha J, Sui B, Su X, Meng Q, Zhang C (2017) Alteration of oxidative stress and inflammatory cytokines induces apoptosis in diabetic nephropathy. Mol Med Rep 16, 7715-7723.

[40] Browne JA, Liu X, Schnaper HW, Hayashida T (2013) Serine-204 in the linker region of Smad3 mediates the collagen-I response to TGF-beta in a cell phenotype-specific manner. Exp Cell Res 319, 2928-2937.

[41] Nho K, Kueider-Paisley A, Ahmad S, MahmoudianDehkordi S, Arnold M, Risacher SL, Louie G, Blach C, Baillie R, Han X, Kastenmuller G, Trojanowski JQ, Shaw LM, Weiner MW, Doraiswamy PM, van Duijn C, Saykin AJ, KaddurahDaouk R, Alzheimer's Disease Neuroimaging Initiative, the Alzheimer Disease Metabolomics Consortium (2019) Association of altered liver enzymes with Alzheimer disease diagnosis, cognition, neuroimaging measures, and cerebrospinal fluid biomarkers. JAMA Netw Open 2, e197978.

[42] Miklossy J, Qing H, Radenovic A, Kis A, Vileno B, Laszlo F, Miller L, Martins RN, Waeber G, Mooser V, Bosman F, Khalili K, Darbinian N, McGeer PL (2010) Beta amyloid and hyperphosphorylated tau deposits in the pancreas in type 2 diabetes. Neurobiol Aging 31, 1503-1515.
[43] Kaur D, Sharma V, Deshmukh R (2019) Activation of microglia and astrocytes: A roadway to neuroinflammation and Alzheimer's disease. Inflammopharmacology 27, 663-677.

[44] Xiang Y, Bu XL, Liu YH, Zhu C, Shen LL, Jiao SS, Zhu XY, Giunta B, Tan J, Song WH, Zhou HD, Zhou XF, Wang YJ (2015) Physiological amyloid-beta clearance in the periphery and its therapeutic potential for Alzheimer's disease. Acta Neuropathol 130, 487-499.

[45] Wang K, Kestenbaum B (2018) Proximal tubular secretory clearance: A neglected partner of kidney function. Clin J Am Soc Nephrol 13, 1291-1296.

[46] Igarashi K, Yoshida M, Waragai M, Kashiwagi K (2015) Evaluation of dementia by acrolein, amyloid-beta and creatinine. Clin Chim Acta 450, 56-63.

[47] Viggiano D, Wagner CA, Martino G, Nedergaard M, Zoccali C, Unwin R, Capasso G (2020) Mechanisms of cognitive dysfunction in CKD. Nat Rev Nephrol 16, 452-469.

[48] Agarwal D, Elks CM, Reed SD, Mariappan N, Majid DS, Francis J (2012) Chronic exercise preserves renal structure and hemodynamics in spontaneously hypertensive rats. Antioxid Redox Signal 16, 139-152.

[49] Liu H, Zhang Z, Li Y, Wang X, Zhang Y, Chu Y, Yuan X, Wang X (2018) Preparation and evaluation of anti-renal fibrosis activity of novel truncated TGF-beta receptor type II. Biotechnol Appl Biochem 65, 834-840.

[50] Tang PM, Zhang YY, Mak TS, Tang PC, Huang XR, Lan HY (2018) Transforming growth factor-beta signalling in renal fibrosis: From Smads to non-coding RNAs. J Physiol 596, 3493-3503.

[51] Chung S, Overstreet JM, Li Y, Wang Y, Niu A, Wang S, Fan X, Sasaki K, Jin GN, Khodo SN, Gewin L, Zhang MZ, Harris RC (2018) TGF-beta promotes fibrosis after severe acute kidney injury by enhancing renal macrophage infiltration. JCI Insight 3, e123563.

[52] Aragon E, Wang Q, Zou Y, Morgani SM, Ruiz L, Kaczmarska Z, Su J, Torner C, Tian L, Hu J, Shu W, Agrawal S, Gomes T, Marquez JA, Hadjantonakis AK, Macias MJ, Massague J (2019) Structural basis for distinct roles of SMAD2 and SMAD3 in FOXH1 pioneer-directed TGF-beta signaling. Genes Dev 33, 1506-1524.

[53] Inazaki K, Kanamaru Y, Kojima Y, Sueyoshi N, Okumura K, Kaneko K, Yamashiro Y, Ogawa H, Nakao A (2004) Smad3 deficiency attenuates renal fibrosis, inflammation, and apoptosis after unilateral ureteral obstruction. Kidney Int $\mathbf{6 6}$, 597-604.

[54] Ma FY, Sachchithananthan M, Flanc RS, Nikolic-Paterson DJ (2009) Mitogen activated protein kinases in renal fibrosis. Front Biosci (Schol Ed) 1, 171-187.

[55] Stambe C, Atkins RC, Tesch GH, Masaki T, Schreiner GF, Nikolic-Paterson DJ (2004) The role of p38alpha mitogenactivated protein kinase activation in renal fibrosis. $\mathrm{J} \mathrm{Am}$ Soc Nephrol 15, 370-379.

[56] Lee J, An JN, Hwang JH, Lee H, Lee JP, Kim SG (2019) p38 MAPK activity is associated with the histological degree of interstitial fibrosis in IgA nephropathy patients. PLoS One 14, e0213981.

[57] Ma FY, Flanc RS, Tesch GH, Han Y, Atkins RC, Bennett BL, Friedman GC, Fan JH, Nikolic-Paterson DJ (2007) A pathogenic role for c-Jun amino-terminal kinase signaling in renal fibrosis and tubular cell apoptosis. J Am Soc Nephrol 18, 472-484.

[58] Grynberg K, Ma FY, Nikolic-Paterson DJ (2017) The JNK signaling pathway in renal fibrosis. Front Physiol 8, 829. 
[59] Kim ES, Kim MS, Moon A (2004) TGF-beta-induced upregulation of MMP-2 and MMP-9 depends on p38 MAPK, but not ERK signaling in MCF10A human breast epithelial cells. Int J Oncol 25, 1375-1382.

[60] Wu Y, Wang L, Deng D, Zhang Q, Liu W (2017) Renalase protects against renal fibrosis by inhibiting the activation of the ERK signaling pathways. Int J Mol Sci 18, 855.

[61] Juhasz T, Matta C, Somogyi C, Katona E, Takacs R, Soha RF, Szabo IA, Cserhati C, Szody R, Karacsonyi Z, Bako E, Gergely P, Zakany R (2014) Mechanical loading stimulates chondrogenesis via the PKA/CREB-Sox9 and PP2A pathways in chicken micromass cultures. Cell Signal 26, 468-482.

[62] Heldin CH, Moustakas A (2016) Signaling receptors for TGF-beta family members. Cold Spring Harb Perspect Biol 8, a022053.

[63] Oliveira JM, Henriques AG, Martins F, Rebelo S, da Cruz e Silva OA (2015) Amyloid-beta modulates both AbetaPP and tau phosphorylation. J Alzheimers Dis 45, 495-507.

[64] Gong CX, Shaikh S, Wang JZ, Zaidi T, Grundke-Iqbal I, Iqbal K (1995) Phosphatase activity toward abnormally phosphorylated tau: Decrease in Alzheimer disease brain. J Neurochem 65, 732-738.

[65] Molkentin JD (2004) Calcineurin-NFAT signaling regulates the cardiac hypertrophic response in coordination with the MAPKs. Cardiovasc Res 63, 467-475.

[66] Adams DG, Coffee RL, Jr., Zhang H, Pelech S, Strack S, Wadzinski BE (2005) Positive regulation of Raf1-MEK1/2ERK1/2 signaling by protein serine/threonine phosphatase 2A holoenzymes. J Biol Chem 280, 42644-42654.

[67] Bautista-Nino PK, Portilla-Fernandez E, Rubio-Beltran E, van der Linden JJ, de Vries R, van Veghel R, de Boer M, Durik M, Ridwan Y, Brandt R, Essers J, Menzies RI, Thomas R, de Bruin A, Duncker DJ, van Beusekom HMM, Ghanbari M, Hoeijmakers JHJ, Sedlacek R, Touyz RM, Montezano AC, van der Pluijm I, Danser AHJ, Haanes KA, Roks AJM (2020) Local endothelial DNA repair deficiency causes aging-resembling endothelial-specific dysfunction. Clin Sci (Lond) 134, 727-746.

[68] Gulbis JM, Kelman Z, Hurwitz J, O’Donnell M, Kuriyan J (1996) Structure of the C-terminal region of p21(WAF1/CIP1) complexed with human PCNA. Cell 87, 297-306

[69] Ma X, Jiao Z, Liu Y, Chen J, Li G, Liu T, Tse G, Yuan R (2019) Probucol protects against contrast-induced acute kidney injury via the extracellular signal-regulated kinases 1 and 2 (ERK1/2)/JNK-caspase 3 pathway in diabetic rats. Med Sci Monit 25, 1038-1045.
[70] Rodriguez R, Meuth M (2006) Chk1 and p21 cooperate to prevent apoptosis during DNA replication fork stress. $\mathrm{Mol}$ Biol Cell 17, 402-412.

[71] Park G, Nhan HS, Tyan SH, Kawakatsu Y, Zhang C, Navarro M, Koo EH (2020) Caspase activation and caspase-mediated cleavage of APP is associated with amyloid beta-proteininduced synapse loss in Alzheimer's disease. Cell Rep 31, 107839.

[72] Chen L, Yang T, Lu DW, Zhao H, Feng YL, Chen H, Chen DQ, Vaziri ND, Zhao YY (2018) Central role of dysregulation of TGF-beta/Smad in CKD progression and potential targets of its treatment. Biomed Pharmacother 101, 670-681.

[73] Duffield JS (2014) Cellular and molecular mechanisms in kidney fibrosis. J Clin Invest 124, 2299-2306.

[74] Giannandrea M, Parks WC (2014) Diverse functions of matrix metalloproteinases during fibrosis. Dis Model Mech 7, 193-203.

[75] Flevaris P, Vaughan D (2017) The role of plasminogen activator inhibitor type-1 in fibrosis. Semin Thromb Hemost 43, 169-177.

[76] Szentleleky E, Szegeczki V, Karanyicz E, Hajdu T, Tamas A, Toth G, Zakany R, Reglodi D, Juhasz T (2019) Pituitary adenylate cyclase activating polypeptide (PACAP) reduces oxidative and mechanical stress-evoked matrix degradation in chondrifying cell cultures. Int J Mol Sci 20, 168.

[77] Huang D, Liu Y, Huang Y, Xie Y, Shen K, Zhang D, Mou Y (2014) Mechanical compression upregulates MMP9 through SMAD3 but not SMAD2 modulation in hypertrophic scar fibroblasts. Connect Tissue Res 55, 391-396.

[78] Bengatta S, Arnould C, Letavernier E, Monge M, de Preneuf HM, Werb Z, Ronco P, Lelongt B (2009) MMP9 and SCF protect from apoptosis in acute kidney injury. $J$ Am Soc Nephrol 20, 787-797.

[79] Shimbori C, Upagupta C, Bellaye PS, Ayaub EA, Sato S, Yanagihara T, Zhou Q, Ognjanovic A, Ask K, Gauldie J, Forsythe P, Kolb MRJ (2019) Mechanical stress-induced mast cell degranulation activates TGF-beta 1 signalling pathway in pulmonary fibrosis. Thorax $\mathbf{7 4}, 455-465$.

[80] Swartz MA, Tschumperlin DJ, Kamm RD, Drazen JM (2001) Mechanical stress is communicated between different cell types to elicit matrix remodeling. Proc Natl Acad Sci U S A 98, 6180-6185. 